\title{
Kakvo Izborno zakonodavstvo vodi BiH u društvo evropskih naroda?
}

\author{
Slavo Kukić \\ Redovni član \\ Akademije nauka i umjetnosti Bosne i Hercegovine \\ slavo.kukic@tel.net.ba
}

\begin{abstract}
Sažetak: Koliko god politička demokracija nije idealnotipsko rješenje za ostvarenje principa društvene pravde i jednakosti, na današnjemu stupnju razvoja ona znači najmanje odstupanje od tih principa. Nažalost, unutar nje su mnoga rješenja koja znače, manje ili više očigledan odmak i od onoga što politička demokracija može dosegnuti. Bosanskohercegovačko iskustvo, utemeljeno na Izbornom zakonu iz 2001. godine, u prilog tome najzornije svjedoči. Jer nedorečenosti, koje su u njemu i više nego evidentne, su 20 godina njegova funkcioniranja bile razlogom za nezadovoljstvo gotovo svih aktera u bosanskohercegovačkoj političkoj areni. Stoga se od prvog dana njegova života mogu pratiti i kritike na veliki dio, u njemu ugrađenih rješenja pri čemu se i zakon nerijetko optužuje kao uzrok individualne i kolektivne neravnopravnosti bosanskohercegovačkih građana i naroda, ali i zahtjevi da se zakon mijenja kako bi se eliminirali uzroci nejednakosti, neravnopravnosti, disfunkcionalnosti državnih i inih institucija itd. Pitanje je, međutim, koji smjer i pravac promjena u izbornomu zakonodavstvu tim zahtjevima i eliminaciji apostrofiranih uzroka mogu udovoljiti? U ovom radu su ponuđeni neki od principa koji bi na tom tragu mogli biti.
\end{abstract}

Ključne riječi: Izborni zakon, principi reforme, odnos individualnog i kolektivnog, prijedlog HDZ-a, prijedlog SDP-DF

\section{Uvodne napomene}

Krajnje pogrešno bi političku demokraciju bilo tretirati optimalnim, kamoli idealnim rješenjem za materijalizaciju kriterija društvene pravde i jednakosti. Zapravo, da bi se o tome uopće moglo govoriti neophodna pretpostavka bi morao biti odgovor na pitanje što podrazumijevati pod apostrofiranim, kriterijima društvene pravde i jednakosti? Dominantni pristup tim kriterijima, naime, vrlo teško može zadovoljiti i princip pravde i princip jednakosti. Potpuno suprotno, u svim političkim sistemima dosadašnje povijesti politička demokracija se, manje ili više eksplicitno, iskazivala kao instrument masovne manipulacije. I gotovo je izvjesno da će, ne dogode li se bitne promjene u fenomenološkoj strukturi političke demokracije, masovna manipulacija ostati njezino najznačajnije poslanje i u budućnosti. 
Naravno, ambicija ove analize nije ta dimenzija političke demokracije kao filozofskog, politološkog, sociološkog fenomena. Naprotiv, nju se u potpunosti apstrahira, a intelektualna pozornost koncentrira na neku vrstu komparativne analize, bolje reći na to da se temeljne postulate političke demokracije u Bosni i Hercegovini, one iz Izbornog zakona BiH prije svega, stavi u odnos s najbitnijim odrednicama tog istog fenomena u društvima razvijenih političkih demokracija. I da se, sukladno tome, traga za promjenama koje bi eventualni jaz između konkretnih bosanskohercegovačkih i rješenja u društvima razvijenih demokracija, ako ne u potpunosti eliminirala onda barem svela na najmanju moguću mjeru.

\section{Nekoliko kronoloških pripomena u vezi s Izbornim zakonom Bosne i Hercegovine}

Izborni zakon BiH, usvojen prije gotovo dva desetljeća ${ }^{1}$, je kroz čitav svoj dosadašnji život bio uzrokom društvenih sporenja, trvenja i, nerijetko i veoma zaoštrenih, političkih konflikata. Ako je, naime, temeljem njegova, poprilično dugog života suditi, Izbornim zakonom iz 2001. godine od prvog dana nije bio zadovoljan nitko - kako oni iz grupacije etnonacionalnih političkih filozofija, tako ni oni iz stranaka građanske provenijencije. No, nikada do danas nije osiguran potreban minimum političkog konsenzusa kako bi se došlo do promjena koje su na tragu standarda razvijenih demokracija, a koji istodobno imaju većinsku potporu bosanskohercegovačkoga parlamenta. Nisu pomogli ni relativno učestali pokušaji moderiranja SAD i EU, ali ni institucija međunarodne zajednice u $\mathrm{BiH}$, kao ni intervencije Venecijanske komisije ${ }^{2} \mathrm{u}$ odnosu na važeća rješenja, ali i u odnosu na prijedloge koje kao rješenja nude domaći politički akteri. Dapače, izostanak potpore vlastitim i pozitivan odnos prema rješenjima drugih sudionika u procesu usuglašavanja je često tumačen

\footnotetext{
${ }^{1}$ U Službenom glasniku BiH br. 23/01 je, još preciznije, zakon objavljen 15. rujna 2001. godine. Izmjenama i dopunama je, potom, u tekst zakona intervenirano čak 19 puta (Službeni glasnik 7/02, 9/02, 20/02, 25/02, 4/04, 20/04, 25/05, 52/05, 65/05, 77/05, 11/06, 24/06, 32/07, 33/08, 37/08, 32/10, 18/13, $7 / 14$, i $31 / 16)$

${ }^{2}$ Evropska komisija za demokraciju kroz pravo, poznatija kao Venecijanska komisija, je savjetodavno tijelo Vijeća Evrope koje se bavi ustavnim pitanjima, izbornim pitanjima i općenito djelovanjem demokratskih ustanova, koje je 1990. godine formiralo 18 država članica Vijeća Evrope. Danas se u njezinu članstvu nalazi 61 država, uključujući i izvanevropske zemlje (47 država članica Vijeća Evrope i još 14 drugih zemalja - Alžir, Brazil, Čile, Kostarika, Izrael, Kazahstan, Republika Koreja, Kosovo, Kirgistan, Maroko, Meksiko, Peru, Tunis i SAD) s zajedno preko tri milijarde stanovnika . Uloga komisije je pružanje pravnih savjeta državama članicama, posebno pomoći državama koje žele uskladiti svoje pravne $\mathrm{i}$ institucionalne strukture s evropskim standardima i međunarodnim iskustvom u oblasti demokracije, ljudskih prava i zakona.
} 
krunskim dokazom svrstavanja svijeta u raspetljavanju bosanskohercegovačkog gordijskog čvora na jednu stranu.

Uzrok izostanka mogućnosti usuglašavanja zajedničkog rješenja su međusobno potpuno suprotstavljeni interesi triju etničkih političkih grupacija - o nemogućnosti da se oni pomire s rješenjima koja se nude iz bloka građanskih političkih partija, partija političke ljevice posebice, da se i ne govori.

Generalno, rješenja za promjene Izbornog zakona u prethodna dva desetljeća slijedila su jednu od tri logike. Prva se koncentrira oko modela koje nude stranke građanske orijentacije, a kojima se vrlo često priklanja i SDA. Radi se o logici koja zagovara snažnije naglašavanje građanskoga u odnosu na etnički princip u reformi Izbornog zakona. Pri tome se isti princip i ista logika želi primijeniti i na zemlju kao cjelinu i na sve njezine dijelove. Naravno, takav pristup podrazumijeva značajnije intervencije i u Ustav i u Izborni zakon, posebice radi li se o izboru članova Predsjedništva $\mathrm{BiH}$, te domova naroda i na razini zemlje i na razini entiteta.

Druga, logika koju promoviraju, i nude kao općebosanskohercegovačku, HDZ, a pod njezinom dirigentskom palicom i ostale stranke s hrvatskim predznakom, okupljene oko tzv. Hrvatskog narodnog sabora, slijedi princip intervencija i u Ustav i u Izborni zakon koje element nacionalnog potencira značajno više no što je isti potenciran u postojećim rješenjima, ali i element građanskoga faktički eliminira na svim, osim na razini lokalne samouprave.

Treća logika, na koncu, dolazi od stranaka sa sjedištem u Republici Srpskoj. U pitanju je logika u čijoj strukturi ima elemenata koji su zajednički, ali i onih u kojima se dvije temeljne političke grupacije ovog dijela zemlje razlikuju.

Name, SNSD i stranke pod njegovom kontrolom se priklanjaju rješenju nacionalnih reprezentacija, bilo da one dolaze iz triju prostornih nacionalnih entiteta, bilo da su formirane na drugi način, a koje kao bosanskohercegovački koncept nudi HDZ uz potporu drugih članica tzv. HNS-a. Jedini uvjet koji ova grupacija ima jeste da takvo rješenje ne može ni na koji način zadirati i u Republiku Srpsku. Drugim riječima, podržava se rješenje HDZ BiH, ali samo na prostoru Federacije, nikako i na razini zemlje kao cjeline koja uključuje i Republiku Srpsku. Još konkretnije, prava Hrvata, za koje se zalaže HDZ, a koje podržava SNSD - isto je, dakako, i s pravima Bošnjaka u ovom dijelu zemlje - ne odnose se i na Hrvate na prostoru Republike Srpske.

S druge strane, grupacija, čiju kralježnicu čine SDS i PDP, podržava opredjeljenje da je izborni sustav Republike Srpske stvar ovog dijela zemlje koja isključuje pravo političkim akterima s prostora Federacije da u njegovim 
reformama na bilo koji način i sami sudjeluju. Za razliku, međutim, od SNSD, članice ove grupacije ni na koji način ne žele biti prevaga ni u vezi s rješenjima u Izbornom zakonu koja se odnose na prostor Federacije BiH.

Uz navedeno, dakako, postoje i detalji oko kojih je, inzistiranjem da ih se ugradi u Izborni zakon, formirana mreža velikog broja političkih partija izuzimajući SDA, HDZ i SNSD - ali i drugih aktera, među njima i Centralne izborne komisije, na razini cijele zemlje. U pitanju su rješenja koja se tiču instituta izvanrednih izbora, ali i ona koja omogućuju da izbori budu istinski odraz volje biračkog tijela i isključuju ili barem na najmanju moguću mjeru svode mogućnost zloupotreba izbornog procesa. Pri tome se misli, prije svega, na uvođenje u izborni proces novih tehnologija, odnosno elektronskog glasovanja, uvođenje nezavisne funkcije predsjednika biračkih odbora kojeg bi se biralo putem javnog oglasa u neizbornoj godini, uvođenje novčanih sankcija za političke subjekte za čije predložene članove biračkih odbora se utvrdi da su prekršili odredbe Izbornog zakona $\mathrm{BiH}$, uvođenje ranog glasovanja za birače sa pravom glasa koji na dan izbora iz opravdanih razloga nisu u mogućnosti glasovati na svom biračkom mjestu, sprečavanje zloupotrebe nacionalnog izjašnjavanja ugrađivanjem odredbi kojima se takva mogućnost isključuje itd. Tu vrstu promjena, istina, verbalno podržavaju i tri dominantne etnonacionalne filozofije, dok stvarno pružaju snažan otpor i blokiraju reforme izbornoga zakonodavstva kojima bi one bile i omogućene.

Nesporno je, potom, da su presude bosanskohercegovačkih sudova dobivale različita tumačenja od strane političkih aktera koji participiraju i u raspravama o reformi izbornoga zakonodavstva. Pri tome se misli, među inim, i na presudu u predmetu Ljubić od 1. prosinca 2016. godine. U odnosu na nju se, istine radi, kako bi nesporazume eliminirao, nikada nakon donesene presude nije odredio ni sam Ustavni sud.

Pri tome je, međutim, važno da je u HDZ-ovu tumačenju ta presuda Ustavnog suda značila obvezu izmjene, ne samo Izbornog zakona, nego i Ustava Federacije, i to izmjena koja bi bila na tragu rješenja kojeg iz presude Ustavnoga suda iščitava baš ta politička partija. No, važno je i to da je u slučaju zahtjeva za ocjenom usklađenosti Ustava Federacije s Ustavom BiH, a na zahtjev predsjedavajuće Zastupničkog doma državnoga parlamenta ${ }^{3}$, Ustavni sud $\mathrm{BiH}$ obustavio postupak. Pri tome je elementarno pitanje zašto zahtjev za obustavom postupka u slučaju za koji se tvrdi da nije usklađen s Ustavom BiH i da se njime nanosi šteta čitavom jednom narodu? Lider HDZ

\footnotetext{
${ }^{3}$ U pitanju je Borjana Krišto, zastupnica HDZ BiH u Zastupničkom domu Parlamentarne skupštine BiH u mandatu 2014-2018. godine.
} 
da je javnosti objašnjavao kao „doprinos HDZ-a BiH unapređenju izbornog zakonodavstva u $\mathrm{BiH}^{\text {“4 }}$. Stvarni razlog je, međutim, u sasvim drugom - u želji da se obustavom postupka preduprijedi odluka Ustavnog suda koja ne bi bila na tragu zahtjeva i ambicija HDZ-a - a, po svemu sudeći, raspolagalo se informacijama kako bi se baš to moglo dogoditi. ${ }^{5}$

Nesporno je, na koncu, promatraju li se rasprave o pravcima reformi izbornoga zakonodavstva u prethodna dva desetljeća - a za neke od njih je jedna od pretpostavki i reforma Ustava - da su se SAD, EU i Venecijanska komisija u pravilu svrstavali uz rješenja građanskih političkih partija, zapravo svojim mišljenjima davali za pravo njihovim rješenjima kao rješenjima koja slijede evropske demokratske standarde. To se, uostalom, dogodilo i u vezi s presudom u slučaju Ljubić jer su sugestije Venecijanske komisije o tome kako presudu implementirati na tragu rješenja koja su ponudile stranke građanskoga političkog spektra, prije svega one koje se nominiraju strankama političke ljevice. ${ }^{6}$

Generalno se, dakle, može reći da u vezi s potrebom reformi izbornoga zakonodavstva postoji suglasnost aktera bosanskohercegovačke političke scene. No, izvjesno je i da u vezi sa smjerom tih reformi ne postoji ni minimum političkog konsenzusa. Izvjesno je, potom, da se promjene izbornog zakonodavstva, i to prema rješenjima koja dolaze iz pojedinih centara političke moći, koriste kao instrument blokada svih institucija političkog i državnog sistema ${ }^{7}$, a sva druga rješenja tretiraju kao atak, ne samo na narod nego i na državu. ${ }^{8}$ I

\footnotetext{
${ }^{4}$ Čović: Krišto je povukla svoju apelaciju, to je HDZ-ov doprinos unapređenju izbornog zakonodavstva, https://www.faktor.ba/vijest/covic-kristo-je-povukla-svoju-apelaciju-to-je-hdz-ov-doprinos-unapredenju-izbornog-zakonodavstva/41536, Objavljeno: 25. 6. 2019, pristupljeno 11. 6. 2020.

${ }^{5}$ Razlog apelacije gospođe Krišto je, podsjetimo, bilo njezino uvjerenje da ustavna formulacija iz Ustava Federacije $\mathrm{BiH}$, prema kojoj se iz svakog kantona u Dom naroda bira najmanje po jedan pripadnik svakog konstitutivnog naroda, ukoliko je takav izabran u zakonodavno tijelo tog kantona, nije u skladu s Ustavom BiH.

${ }^{6}$ Venecijanska komisija poručila da se problem Izbornog zakona može riješiti i na nivou FBiH, https:// www.klix.ba/vijesti/bih/venecijanska-komisija-porucila-da-se-problem-izbornog-zakona-moze-rijesiti-i-na-nivou-fbih/180524039, objavljeno 24. 5. 2018, pristupljeno 9. 6. 2020.

${ }^{7}$ Čović: Vlada FBiH neće biti formirana sve dok se ne izmijeni Izborni zakon BiH, https://www. klix.ba/vijesti/bih/covic-vlada-fbih-nece-biti-formirana-sve-dok-se-ne-izmijeni-izborni-zakonbih/190121080, objavljeno 21. 1. 2019, pristupljeno 10. 6.2020.

Čović u Jajcu: Bez izmjene Izbornog zakona nema nove Vlade FBiH, https://www.klix.ba/vijesti/covic-u-jajcu-bez-izmjene-izbornog-zakona-nema-nove-vlade-fbih/200226029, objavljeno 26. 2. 2020, pristupljeno 10.6. 2020.

Dodik dodao uslov: Blokada dok se ne riješi pitanje stranih sudija, ali i Izborni zakon, https://www. klix.ba/vijesti/bih/dodik-dodao-uslov-blokada-dok-se-ne-rijesi-pitanje-stranih-sudija-ali-i-izborni-zakon/200213141, objavljeno 13. 2. 2020, pristupljeno 10. 6. 2020.

${ }^{8}$ Božo Ljubić: "Bošnjačke" stranke su izvršile entitetski udar na državu, https://www.klix.ba/vijesti/ bih/bozo-ljubic-bosnjacke-stranke-su-izvrsile-entitetski-udar-na-drzavu/180707045, objavljeno 7.7. 2018, pristupljeno 10. 6. 2020.
} 
da se prijeti rezervnim, rješenjima koja se u javnosti ne pojašnjavaju, a koja daju mogućnost spekulacijama i on najradikalnijim scenarijima. ${ }^{9}$ Ali i da se iz istih centara odbija pomoć svjetskih međunarodne zajednice, SAD i EU prije svega, i Venecijanske komisije u traganju za rješenjem koje bi bilo na tragu evropskih standarda i vrijednosti $-\mathrm{i}$ istodobno sve eksplicitnije traži da ih se, pod izgovorom da su pristrani, isključi iz procesa izmjena izbornoga zakonodavstva. $^{10}$

\section{Prijedlozi koji zrcale konceptualne razlike između glavnih aktera u procesu traganja za konsezualnim rješenjem promjena Izbornog zakona}

Od 2015. godine je ponuđeno nekoliko prijedloga izmjena i dopuna Izbornog zakona. U kontekstu ove analize će biti prikazana dva - jedan kojeg je u parlamentarnu proceduru uputio HDZ uz potporu stranaka tzv. Hrvatskog narodnog sabora i drugi, kojeg su ponudili SDP i DF, a naknadno im se pridružile i SDA i SBB, a potporu je dobio i od Naše stranke.

U travnju 2017. godine HDZ BiH je, i to po hitnom postupku - isključujući mogućnost razgovora ili, eventualno, amandmanskih intervencija - uputio prijedlog svoga Izbornog zakona. Isti je obrazlagan tezom da se njime Hrvatima kani vratiti dostojanstvo i osjećaj da su svoji na svome, te da će u protivnom oni, Hrvati, i dalje ostati građani drugog reda.

Rješenja, međutim, koja se njime nude nisu na tragu ni vraćanja dostojanstva, ni njihova drugačijeg tretmana, kao što nisu ni u funkciji tretmana svih drugih kao ravnopravnih građana zemlje u kojoj žive. Nigdje, recimo, u tom prijedlogu ni slova o promjenama kojima se Hrvatima na prostoru RS-a - i ne-Srbima ovog dijela zemlje uopće - vraća dostojanstvo. ${ }^{11}$

Predloženim se rješenjima, potom, $u$ isti, položaj građana drugog reda, dovodi i velik dio Hrvata Federacije - i Bošnjaka dakako, a Srbi u tom statusu, poput Hrvata i Bošnjaka RS-a, su ionako sve ove godine. Jer, postojeća rješenja im, ako ništa, osiguravaju i elementarno dostojanstvo i osjećaj

\footnotetext{
${ }^{9}$ Slavo Kukić o Čovićevom "planu B": Cilj je vlast naredne četiri godine po principu ultimatuma, https://www.klix.ba/vijesti/bih/slavo-kukic-o-covicevom-planu-b-cilj-je-vlast-naredne-cetiri-godinepo-principu-ultimatuma/180515050, objavljeno 15. 5. 2018, pristupljeno 8. 6. 2020.

${ }^{10}$ Radmanović: Strance treba isključiti iz procesa izmjena Izbornog zakona, nisu dobronamjerni, https:// www.klix.ba/vijesti/bih/radmanovic-strance-treba-iskljuciti-iz-procesa-izmjena-izbornog-zakona-nisu-dobronamjerni/180508057, objavljeno 8. 5. 2018, pristupljeno 10. 6. 2020.

${ }^{11}$ A uopće se ne radi o brojkama koje je dopušteno ignorirati. Jer, u Republici Srpskoj prema popisima 2013. godine živi 171.839 Bošnjaka, 29.645 Hrvata i 25.640 Ostalih - ukupno 227.124 stanovnika neSrbina (Popisi 2013, statistika.ba)
} 
građana iste vrijednosti sa svima ostalima. A rješenjima koja nude ,zaštitnici“ njihovih nacionalnih prava, sve to gube.

Zašto? Zato što po postojećem Izbornom zakonu glas svakog Hrvata na prostoru Federacije, kada je izbor člana državnoga predsjedništva po srijedi, ima istu vrijednost. Po HDZ-ovu prijedlogu njegovih izmjena toga definitivno nestaje. Drugim riječima, uvodi se podjela na Hrvate prvog i drugog reda. ${ }^{12}$ Sve izrečeno, dakako, vrijedi i za Bošnjake koji žive u području B, u kojem Hrvati, prema prijedlogu izmjena i dopuna HDZ BiH, imaju iznad dvotrećinske većine ukupne populacije.

Pitate se, naravno, na čemu ovakav sud temeljim? Na, prije svega, predloženom rješenju da za člana državnoga predsjedništva može biti biran samo onaj tko većinu glasova dobije na potezu od Neuma i Ravna, pri čemu relevantni nisu čak ni glasovi Mostara, do Kupresa i Livna - uz dodatak, istina, da im se pridružuju i glasovi Posavine. Bez njih, hoću reći, ne pomaže ni činjenica da imaš i dva puta više hrvatskih glasova od ostalih.

Ako je, pak, tako, predloženo rješenje vrlo realnim čini i sljedeći scenarij - da netko u području od Neuma do Kupresa i Livna osvoji svega koju desetinu tisuća glasova Hrvata, ali u Mostaru i ostatku tzv. područja „C“, a potom i ostatku Federacije - Tuzli, Sarajevu, zeničko-dobojskom kantonu, Bihaću, drugdje - osvoji u zbroju 200 tisuća glasova sunarodnika, ali član državnoga predsjedništva ne može biti. Dapače, na tu će poziciju biti izabran onaj tko je od Neuma do Livna, plus Posavina i još nekoliko teritorijalnih enklavica unutar Federacije BiH, osvojio najviše glasova - pa taman to bilo i dva puta manje od onoga tko ih zaradi u maloprije navedenim područjima.

Slično je i s Domom naroda federalnog, a onda, po zakonu spojenih posuda, i državnoga parlamenta. Jer, među 17 delegata federalnog Doma naroda, niti na jedno mjesto - evo da se apstrahira Goražde u kojem, prema autorima prijedloga izmjena i dopuna Izbornog zakona, Hrvata i nema - ne mogu računati Hrvati Sarajevskog ili, recimo, Unsko-sanskog kantona. Pa, zar oni, ako je tako, nisu građani drugog reda? Kao što su, u slučaju izbora člana Predsjedništva BiH, to isto i svi oni iz Mostara, Kiseljaka, Travnika, Viteza, Fojnice, Vareša, Žepča, nisu li u kombinaciji sa Širokobriježanima, Gruđanima, Ljubušacima, Livnjacima nego, ne daj Bože, recimo, sa Sarajlijama, Zeničanima, Bugojancima, Tuzlacima.

Što na to reći? Hadezeov prijedlog izmjena Izbornog zakona neodoljivo asocira na praksu Pavelićeve endehazije - žrtvovanje Istre, Zadra i otoka

\footnotetext{
${ }^{12}$ Primjerice, predloženim rješenjem je 54.138 Hrvata iz područja A, u kojem Bošnjaci čine iznad 2/3 ukupnoga stanovništva, lišeno svakog utjecaja na izbor člana Predsjedništva BiH iz reda Hrvata.
} 
Musoliniju - uz obrazloženje kako žrtvu traži hrvatski interes. Razlika, zapravo, gotovo da i ne postoji. A ako i jeste, samo je u jednom - da je ovdje teško precizirati tko bi trebao biti Musolini. Sve ostalo nalikuje k'o jaje jajetu - da bi jednima bilo kao u loju, žrtvuju se svi ostali.

To je, uostalom, u vrijeme obznanjivanja HDZ-ova prijedloga izmjena Izbornog zakona ustvrdio i biskup banjalučki u intervjuu za jedan bosanskohercegovački medij, ustvrdivši kako je učinak brige „čuvara“ hrvatstva, zapravo, „nepostojanje Hrvata u pola države“. Ne treba, međutim, odbaciti mišljenja da je uvaženi crkveni dužnosnik bio čak i preblag. I da prijedlog izmjena Izbornoga zakona pokazuje kako je stanje stvari i puno gore - da bi Hrvata moglo nestati i s dobrog dijela one druge polovice. Uz dodatak, doduše, dovršetak ,etničkog čišćenja“ zaobišao ne bi ni Srbe i Bošnjake tamo gdje su nominalno u manjini.

Može li, dakle, takav prijedlog, i zahtjevi koji su iza njega, naići na razumijevanje - i aktera domaće politike i svjetskih centara moći, uopće demokratskog svijeta. Teško je takvu mogućnost i zamisliti. No, realni život nerijetko zna praviti i nerazumne kompromise. Mogućnost takvog scenarija, drugim riječima, ne treba isključiti ni u ovom slučaju. Jer, svoje razloge imaju i međunarodni i domaći politički akteri.

Ne jednom u historiji se, naime, dogodilo da svjetski centri moći pristanu na rješenja, o kojima u vlastitim zemljama ne bi spremni bili ni razgovarati. Drugdje se, međutim, nerijetko znaju zadovoljiti i rješenjima kojima se trenutačno smanjuju tenzije, iako ona dugoročno znače klice novih nestabilnosti i novih sukoba. Bosna i Hercegovina je, uostalom, u prethodnih 30 godina to ne jednom i sama iskusila.

S druge strane, ne smije se isključiti da rješenje, ponuđeno u HDZ-ovu prijedlogu, odgovara i bosanskohercegovačkim etnonacionalistima uopće neovisno o tome podržavaju li ga javno ili ne. I da su, uz manje intervencije ili bez njih, u konačnici spremni za njega dići ruke - ne zbog uvjerenja kako je ono interes građana BiH nego, sasvim suprotno, zbog kalkulacija kako bi njime i sami osigurali svoju neupitnost na jednom dijelu države u budućnosti.

No, nije upitno da takva rješenja ne mogu biti zalog evropske budućnosti. A ni, narodski kazano, zalog mirne Bosne. Sasvim suprotno, ono bi samo rehabilitiralo vrijednosti prošlih stoljeća - vrijednosti plemenske logike posebice - i bilo bi temelj budućih etničkih i konfesionalnih sukobljavanja. I, nema dvojbi, kontinuiteta procesa demografskog pražnjenja kojemu, uostalom, svi zajedno svjedočimo i danas. 
Drugi je Prijedlog Zakona o izbornim jedinicama i broju mandata Parlamenta Federacije BiH, kojeg su koncem 2017. godine u proceduru uputili SDP i DF. Zapravo, Demokratska fronta je početkom veljače 2020. godine u parlamentarnu proceduru uputila još jedan, prijedlog Izbornog zakona - uz njega i amandmane na Ustav $\mathrm{BiH}$ - kojeg su uradili njezini pravni eksperti. ${ }^{13}$ No, na njega su po principu „hitno“ reagirali HDZ i SNSD, dajući do znanja kako o tom prijedlogu nisu spremni ni razgovarati.

Samo od sebe se, dakako, nameće pitanje, zbog čega? Što je razlog takvog ignorirajućeg odnosa, neovisno o tome od koga prijedlog dolazio? Vjerojatno ga treba tražiti u činjenici da prijedlog DF-a ne stavlja znak jednakosti između HDZ-a i Hrvata, da integrira a ne dezintegrira, da, u konačnici, puno više štiti Hrvate no što ih štiti i postojeći Izborni zakon. Razlozi su, drugim riječima, tamo gdje su bili i u slučaju Prijedloga Zakona o izbornim jedinicama i broju mandata Parlamenta FBiH, kojeg su koncem 2017. godine u proceduru uputili SDP i DF. A kojeg je HDZ odbacio pod izgovorom da nije u skladu s presudom Ustavnoga suda, da je tu odluku moguće implementirati jedino izmjenama zakona u državnomu parlamentu, nikako i u Parlamentu Federacije $\mathrm{BiH},{ }^{14}$ da će Hrvati rješenjima koja taj prijedlog nudi ponovo biti diskriminirani itd. ${ }^{15}$

\footnotetext{
${ }^{13}$ Prema prijedlogu zakona, kojeg je u parlamentarnu proceduru uputio DF, članovi Predsjedništva BiH bi se birali tako što bi se iz RS-a birao jedan član, i to bez nacionalne odrednice, a iz Federacije $\mathrm{BiH}$ dva, pri čemu ne mogu biti iste nacionalnosti. S druge strane, zastupnici u Dom naroda državnoga parlamenta birali bi se na način da bi se povećao njihov broj, pa bi, uz zastupnike iz reda konstitutivnih naroda, iz svakog entiteta bili birani i pripadnici nacionalnih manjina. Dom naroda parlamenta Federacije $\mathrm{BiH}$ birao bi se tako što bi u njega bio delegiran barem po jedan pripadnik svakog konstitutivnog naroda iz svake županije. Predložen je, na koncu, i novi model izbora zastupnika u gradskom vijeću Mostara, koji bi se birali razmjerno broju stanovnika u određenim dijelovima grada. Predviđeno je i uvođenje novih tehnologija pri glasovanju, te zabrana kandidiranja osobama koje su pravomoćno osuđene za ratne zločine. Uz sve to prijedlog predviđa i druga rješenja koja zaslužuju pažnju. Predviđa se, primjerice, prestanak mandata članovima Predsjedništva ako ne obavljaju svoju funkciju, prestanak mandata izabranim zastupnicima ukoliko Parlamentarna skupština ne izvršava svoje dužnosti, depolitizacija izborne administracije i uvođenje suvremenih tehnoloških rješenja u izborni proces (elektronskih skenera, kamera, čitača otiska prsta ili druge tehničke opreme) itd.

${ }^{14}$ Zanimljivo je da su iz međunarodnih krugova i u vezi s tim dolazili međusobno oprečni signali. Po mišljenju Venecijanske komisije, naime, problem izbornog zakonodavstva, koji je u vezi s presudom Ustavnog suda $\mathrm{BiH}$ u predmetu „Ljubićc može se riješiti na razini Parlamenta Federacije BiH. Drugim riječima, $u$ proceduru upućeni prijedlog se naslanjao na mišljenje Venecijanske komisije. Istodobno, međutim, delegacija Evropske unije u BiH je imala identičan stav kao HDZ BiH, da se odluka Ustavnog suda BiH mora implementirati u Parlamentarnoj skupštini BiH - i time se, praktički, izjasnila protiv prijedloga izmjena Izbornog zakona s kojim su u federalni parlament išle četiri stranke kako bi se njime provela presuda Ustavnog suda BiH u predmetu „Ljubić“.

${ }^{15}$ Budući je prijedlog zakona usvojen u Zastupničkom domu Parlamenta Federacije, predsjednik Glavnog vijeća nevladine udruge Hrvatski narodni sabor je to okarakterizirao činom „derogiranja Ustavnog
} 
Analizira li se, međutim zajednički prijedlog SDP-a i DF-a - uz napomenu da su uz njega naknadno, kao ravnopravni predlagači stali i SDA i SBB, da ga je, iako nije bila potpisnik zajedničkog prijedloga, podržala i Naša stranka, te da je u Zastupničkom domu Parlamenta Federacije BiH i usvojen 20.06.2018. godine $^{16}$ - a koji stvari stoje bitno drugačije u odnosu na tvrdnje HDZ-a. Taj prijedlog, naime, poštuje temeljni princip balansa građanskoga i nacionalnog - koji je conditio sine qua non funkcioniranja BiH i kao države i kao društva. A, otišlo se značajno dalje i od onoga što omogućuje postojeće zakonsko rješenje kada su Hrvati i njihov opstanak u BiH po srijedi.

U prilog izrečenom govore i rješenja iz tog prijedloga. Po njemu, prostor Federacije je podijeljen na 12 izbornih jedinica koje se ne preklapaju nužno s granicama kantona. A time se postiže ravnomjerniji balans između broja birača i broja mandata u građanskom domu federalnog parlamenta. Zapravo, značajno više nego u postojećem rješenju se poštuje evropski princip građanskoga - da jedan mandat pripada približno istom postotku građana u ukupnom biračkom tijelu ovog dijela zemlje.

Predloženim rješenjem SDP-a i DF-a se, potom, osigurava i paritetna zastupljenost Hrvata, Srba i Bošnjaka u Domu naroda federalnog parlamenta, ali i primjerena zastupljenost građana Federacije koji se ne izjašnjavaju pripadnicima triju etniciteta. Rješenje je, prevedeno u brojke, po 17 delegata svakog od triju naroda, sedam onih iz kvote Ostali - pripadnika, dakle, nacionalnih manjina i građana koji se ne svrstavaju ni u jedan od etničkih identiteta.

Istodobno, etničkim je principom udovoljeno i presudi Ustavnoga suda, kojom je neustavnom proglašena odredba u postojećem Izbornom zakonu da se u svakom kantonu za Dom naroda federalnog parlamenta svakom od triju naroda daje jedno mjesto, neovisno o tome kakva je etnička struktura kantonalne skupštine. Predloženim rješenjem se, drugim riječima, doslovce preslikava ustavna odredba, prema kojoj u svakom kantonu za Dom naroda federalnog parlamenta svakom narodu pripada najmanje jedno mjesto, ali pod uvjetom da je u kantonalnu skupštinu biran barem jedan zastupnik iz tog naroda. I to je odredba koju se, ima li se dobre namjere, teško može osporavati. Jer, ne samo da ona proizlazi iz Ustava, nego je i u funkciji zaštite onih koji

\footnotetext{
suda i Ustava BiH te je tako ovih pet bošnjačkih stranaka izvele entitetski udar na državu“ (https://www. klix.ba/vijesti/bih/bozo-ljubic-bosnjacke-stranke-su-izvrsile-entitetski-udar-na-drzavu/180707045) ${ }^{16}$ Zakon o izbornim jedinicama i broju mandata Parlamenta FBiH je usvojen sa 65 glasova „za“ i bez onih protiv ili suzdržanih - uz dodatak, doduše, da tom zasjedanju Zastupničkog doma nisu prisustvovali zastupnici HDZ BiH, i opet uz obrazloženje da je predloženi zakon u suprotnosti s Ustavom BiH, presudom Ustavnog suda BiH i Ustavom Federacije BiH.
} 
su u pojedinim dijelovima zemlje - zbog ratnih strahota, ali i poslijeratnog načina vladanja u gotovo istoj mjeri - ostali u značajnoj brojčanoj manjini.

Zašto, pak, ako je tako, HDZ BiH nije pokazala spremnost da o njemu i razgovara? I što je razlog solidariziranja SNSD-a s takvim stavom? Razlog, po svemu sudeći, što se HDZ-a tiče, treba tražiti u činjenici da predloženo rješenje ne osigurava HDZ-u ekskluzivitet na hrvatsko predstavljanje, niti je garancija njegova bezuvjetnog sudjelovanja u podjeli političke moći. Što se, međutim, solidariziranja SNSD-a tiče, motive treba tražiti u procjeni kako se time pomaže zaoštravanje političkih konflikata i dalje destabiliziranje zemlje koje ide na vodu tezama o BiH kao nemogućoj državi.

Jedino tim motivima je, zapravo, moguće tumačiti odbijanje modela u kojemu je nacionalno izbalansirana struktura Doma naroda državnoga parlamenta na način da se u njemu omogućuje zastupljenost i Srba iz Federacije, odnosno Hrvata i Bošnjaka iz RS-a, ali i grupacije Ostalih s prostora čitave zemlje. S druge strane, eliminira se Dom naroda kao paralelna, institucija kojom se obesmišljava građansko predstavljanje, a njegove ingerencije svode isključivo na pitanja koja se tiču vitalnog nacionalnog interesa - koja se, uz to, prijedlogom i preciziraju. Uvodi se i institut izvanrednih izbora i do detalja razrađuju slučajevi u kojima se primjenjuje - a time se eliminiraju i mogućnosti nepoštivanja iskazane volje birača na izborima kojima sve ove godine, pa i danas svjedočimo. U vezi sa sastavom Predsjedništva države se predlaže rješenje kojim se otklanjaju uzroci diskriminacije po etničkoj osnovi i izvršavaju presude suda u Strasbourgu. Nudi se, na koncu, rješenje i mostarskog izbornog rebusa.

Daleko od toga da je prijedlog SDP i DF bogomdan. Ponešto bih mu se, ako se već hoće, imalo i prigovoriti. Ali, parlament je mjesto gdje se prigovore može i treba iznijeti. Zašto, međutim, unaprijed odbiti svaku mogućnost razgovora? I zašto otvoreno ne reći razlog za to - da se prijedlog ne uklapa u ambicije vrha HDZ. Koji bi preko Izbornog zakonom htio ostvariti ono što mu je cilj bio i tijekom rata - novu podjelu zemlje i teritorijaliziranu hrvatsku jedinicu, kako god se ona zvala. U svakom slučaju, prostor na kojemu će HDZ imati neprikosnovenu vlast i preko kojega će, dok god je on i formalno u sastavu zajedničke države, moći uvjetovati odnose i u njezinim okvirima. Otprilike onako kako to danas čini Dodik, možda u još zaoštrenijoj formi. 


\section{Principi koje bi se kod izbornog zakona moralo ispoštovati}

Ambicija ove analize nije nuditi ni konkretna, ni u pravničkoj formi, uobličena rješenja, kojima bi Izborni zakon $\mathrm{BiH}$ dobio konture istog takvog zakonodavstva razvijenih demokratskih društava. No, moguće je ponuditi principe koje bi u kreiranju takvog zakonodavstva bilo uputno slijediti.

Jedan od njih svakako je jednako pravo svakog punoljetnog građanina da - bez obzira na svoju etničku i rasnu pripadnost, kao i ideološku, religijsku i inu orijentaciju - može birati ili biti biran na svaku od izbornih funkcija u institucijama vlasti. I u odnosu na to pravo, uz sve navedeno, brana ne mogu biti ni bilo koji drugi razlozi - mjesto življenja, teritorijalna pripadnost, administrativna organizacija države i slično. A baš različiti tipovi tih razloga su kočnica ostvarivanju biračkoga prava kao temeljnog ljudskog i građanskog prava mnogih bosanskohercegovačkih građana.

Jedan od temeljnih principa, koje bi moralo slijediti izborno zakonodavstvo - u društvima poput bosanskohercegovačkoga posebice - je zaštita i kolektivnih prava građana. Pri tome se mora odbaciti stereotipe kako je za život građana relevantna samo jedna forma njihove manifestacije, etnička prava, te da sva ostala nisu vrijedna pažnje. Sasvim suprotno, društvo izgrađeno na punini građanskih i ljudskih prava sve njih respektira u istoj mjeri. Istina, bosanskohercegovačko društvo je opterećeno sukobima s etničkim prefiksom, zbog čega potreba poštivanja etničkih prava zaslužuje i dodatnu pažnju. Ali, nju se ni na koji način ne smije razumjeti i kao prihvaćanje njihove glorifikacije u odnosu na sva ostala, pa i u odnosu na pravo čovjeka na normalan život i rad, pravnu i svaku drugu sigurnost, i zadovoljavanje svih ostalih i građanskih i ljudskih prava. Na čisto teorijskoj ravni, istina, u društvu, u kojemu je osigurana punina građanskih i ljudskih prava, po automatizmu su osigurana i kolektivna, pa i etnička prava kao jedan od oblika njihove manifestacije. Imajući, međutim, u vidu konkretnu stvarnost, sve to ne smije biti razlog da se posebno naglašavanje etničkih kao forme kolektivnih prava tretira odstupanjem od, ili skrnavljenje idealnotipskih teorijskih modela.

U oblikovanju izbornoga zakonodavstva, koje bi pratilo standarde razvijenih demokratskih društava, jedan od principa koji se ni na koji način ne smije ignorirati, jeste princip odgovornosti i smjenjivosti izabranih. Taj princip, potom, po automatizmu znači postojanje instituta izvanrednih izbora u slučaju da se ne može formirati parlamentarna većina u organima zakonodavne vlasti, u slučaju da se izgubi parlamentarna većina temeljem koje su formirani organi izvršne vlasti, u slučaju da članovi izabranog tijela - primjerice 
Predsjedništva $\mathrm{BiH}$ - ne obavljaju Ustavom i zakonom povjerenu im funkciju i slično.

Brana rješenjima izbornoga zakonodavstva, koja slijede standarde razvijenih demokracija, ne smije biti niti administrativna teritorijalna organizacija. Da bi se, primjerice, u izborima za Predsjedništvo BiH ili Dom naroda državnoga parlamenta svim građanima osiguralo i aktivno i pasivno biračko pravo, oblik koji to u najpotpunijoj formi omogućuje je onaj po kojemu se čitava $\mathrm{BiH}$ tretira kao jedna izborna jedinica. To, međutim, ne znači da se, i na razini države i na razini entiteta, ne mogu slijediti i drugi modeli, pod uvjetom, razumije se, da se njima osigurava apostrofirano pravo svim punoljetnim građanima.

U odnosu na teritorijalnu organizaciju važna je i još jedna načelna intervencija. Bosna i Hercegovina, naime, spada u red malih evropskih država. Stoga upitnima djeluju različita izborna rješenja na istim razinama njezine organizacije - na razinama etniteta prije svega. Drugim riječima, ništa logičnije od toga da se izbornim zakonodavstvom takve različitosti, asimetrična rješenja koja danas egzistiraju, eliminiraju i sistem izbora, kakav god on bio, unificira.

Bosna i Hercegovina je klasičan primjer poslijekonfliktnog društva, u kojemu su vrlo snažni ostaci ideologija koji su je koštali i uništavanja ljudske supstance i materijalnog razaranja. Stoga bi i izborno zakonodavstvo moralo biti u funkciji obeshrabrivanja i ideologija destrukcije i onih koji takve ideologije promoviraju. Drugim riječima, zakonskim rješenjima bi na izborne i druge javne funkcije bilo uputno onemogućiti one koji osuđivani za teška kaznena djela - djela ratnih zločina i širenja etničke i konfesionalne netrpeljivosti posebice.

I na koncu, pitanje depolitizacije izborne administracije je, sudi li se po dosadašnjem iskustvu, također jedan od bitnih detalja reforme izbornoga zakonodavstva u BiH. Pri tome je krajnje nevažno koju će formu depolitizacije konkretno zakonsko rješenje slijediti. Važno je isključivo da je eliminirana i najmanja mogućnost političke kontrole izborne administracije na svim razinama njezine organizacije - od biračkih odbora i općinskih izbornih komisija do Centralne izborne komisije BiH. I da, s druge strane, takvu, depolitiziranu administraciju prate rješenja koja isključuju i mogućnost zloupotrebe biračkoga prava. Pri tome se, među inim, misli i na ugrađivanje u izborni proces suvremenih tehnoloških rješenja - elektronskih skenera, kamera, čitača otiska prsta ili druge tehničke opreme za koju se procjenjuje da može biti u funkciji regularnosti izbora. 


\section{Umjesto zaključka}

Bez ambicije da se ide do u najsitnije detalje - zbog čega su, među inim, izostavljeni i neki elementi cjeline koja se krije ispod apostrofiranog naslova - ponuđenom analizom je dan kronološki presjek funkcioniranja izbornoga zakonodavstva od 2001. godine, kada je usvojen Izborni zakon $\mathrm{BiH}$, do danas. Iz njega su, dakako, evidentne i sve razlike koje su se manifestirale među najznačajnijim političkim grupacijama, posebice u odnosu na smjer kojeg treba slijediti u reformi izbornoga zakonodavstva.

Pokušalo se, potom, predstaviti i najkarakterističnija rješenja reforme izbornoga zakonodavstva u prethodnih nekoliko godina sa svim vrlinama $i$ manama koje iza njih stoje. Pri tome je težište stavljeno posebice na dva rješenje koje je u parlamentarnu proceduru u državnomu parlamentu uputio HDZ BiH s jedne, te ono koje su kreirali SDP i GF, a naknadno su mu se kao predlagači priključile još dvije političke partije, SDA i SBB.

$\mathrm{Na}$ koncu, u završnom dijelu se pokušalo ponuditi i temeljne principe koje bi se pri reformi izbornoga zakonodavstva, želi li $\mathrm{BiH}$ primjenjivati standarde razvijenih demokratskih društava u sferi izbornoga zakonodavstva, trebalo slijediti. Sedam principa je posebice apostrofirano zbog uvjerenja da bez njihove implementacije u izborni sustav nema ni evropskih standarda ni evropskog sustava vrijednosti kao onog koji određuje bi BiH kao državu i društvo.

\section{Literatura}

Božo Ljubić: "Bošnjačke" stranke su izvršile entitetski udar na državu, https://www. klix.ba/vijesti/bih/bozo-ljubic-bosnjacke-stranke-su-izvrsile-entitetski-udar-na-drzavu/180707045, objavljeno 7. 7. 2018, pristupljeno 13. 6. 2020.

Izborni zakon Bosne i Hercegovine (Neslužbeni prečišćeni tekst), https://izbori.ba/Documents/documents/ZAKONI/Izborni_zakon_PRECISCENI_TEKST-hrv.pdf, pristupljeno 13. 6. 2020.

Izborni zakon po mjeri Čovića ili Komšića: SNSD uz HDZ, ali bez SDA ne mogu ništa, https://www.klix.ba/vijesti/bih/izborni-zakon-po-mjeri-covica-ili-komsica-snsd-uz-hdzali-bez-sda-ne-mogu-nista/191126016, objavljeno 27. 11. 2019, pristupljeno 13. 6. 2020.

Komšićeva stranka predložila parlamentu izmjene izbornog zakona, https://www.jutarnji. $\mathrm{hr} / \mathrm{vijesti/svijet/bosna-i-hercegovina-komsiceva-stranka-predlozila-parlamentu-izmjene-}$ izbornog-zakona/9938065/, objavljeno 5. 2. 2020, pristupljeno 13. 6. 2020.

Kukić, Slavo (2020), Treba li BiH Izborni zakon koji integrira ili onaj koji, kao prijedlog HDZ-a, dijeli?, Heinrich Böll Stiftung, https://ba.boell.org/bs, objavljeno 21. 2. 2020, pristupljeno 13.6. 2020.

Ovako DF zamišlja izborni proces u BiH: Građanska država po mjeri svih, https://www. klix.ba/vijesti/bih/ovako-df-zamislja-izborni-proces-u-bih-gradjanska-drzava-po-mjerisvih/200206086, objavljeno 6. 2. 2020, pristupljeno 13.6. 2020.

Popisi 2013, www.statistika.ba 
Predstavnički dom usvojio Zakon o izbornim jedinicama i broju mandata u Parlamentu FBiH, https:/www.klix.ba/vijesti/bih/predstavnicki-dom-usvojio-zakon-o-izbornim-jedinicama-i-broju-mandata-u-parlamentu-fbih/180620114, objavljeno 20. 6. 2018, pristupljeno 14. 6. 2020.

SDA, SBB, DF i SDP dogovorili zakon o izbornim jedinicama, uskoro na dnevnom redu Parlamenta FBiH, https://www.klix.ba/vijesti/bih/sda-sbb-df-i-sdp-dogovorili-zakon-oizbornim-jedinicama-uskoro-na-dnevnom-redu-parlamenta-fbih/180616045, objavljeno16. 6. 2018, pristupljeno 14. 6. 2020.

SDA, SBB, SDP i DF danas potpisuju prijedlog zakona o izbornim jedinicama FBiH, https:// www.klix.ba/vijesti/bih/sda-sbb-sdp-i-df-danas-potpisuju-prijedlog-zakona-o-izbornimjedinicama-fbih/180617054, objavljeno 18. 6. 2018, pristupljeno 13. 6. 2020.

Zakon o izmjenama i dopunama Izbornog zakona Bosne i Hercegovine, https:/www.javnarasprava.ba/bih/Zakon/1422, objavljeno 17. 1. 2017, pristupljeno 13. 6. 2020.

\section{What Kind of Electoral Legislation is Led in Bosnia and Herzegovina in the Company of European Nations?}

\section{Summary}

As much as the political democracy is not an ideal model of solution for the achievement of social justice principles and equality, in today's level of development, it represents the least variance from those principles. Unfortunately, there are many solutions within it that signify an obvious detachment from what political democracy can accomplish. Experiences in Bosnia and Herzegovina based upon Electoral Law from 2001 are very vivid evidences for such a claim. Because all ambiguities within this Law that are more than evident were in 20 years of its functioning a reason for discontentment of almost all actors within the political arena in Bosnia and Herzegovina. Therefore, since the first days of its life, we can observe many critics regarding bigger part of embedded solutions - whereat the Law is often accused to be the cause for an individual and collective inequality of citizens and people in Bosnia and Herzegovina. Additionally, there are requests for this Law to be changed to eliminate various reasons for inequality, disparities, dysfunctionality of state and other institutions, etc. But the questions are, which way and direction of changes within the electoral legislation can contribute to the elimination of these causes and which kind of demands could be suitable and satisfactory? This article offers some of the principles that could lead to this trace.

Key words: Electoral Law, reform principles, relation between individuality and collectiveness, proposal by HDZ, proposal by SDP-DF 